\title{
Injuries caused by freshwater stingrays in the Tapajós River Basin: a clinical and sociodemographic study
}

\author{
Paulo Afonso Martins Abati[ ${ }^{[1]}$, Pasesa Pascuala Quispe Torrez ${ }^{[1]}$, Francisco Oscar de Siqueira França ${ }^{[1]}$, \\ Fabio Lambertini Tozzi ${ }^{[2]}$, Flávio Mileo Bacelar Guerreiro ${ }^{[2]}$, \\ Suellen Aline Torres dos Santos ${ }^{[2]}$, Sheyla Mara Silva de Oliveira ${ }^{[2]}$ \\ and Vidal Haddad Junior ${ }^{[3]}$
}

\author{
[1]. Departamento de Moléstias Infecciosas e Parasitárias, Núcleo de Medicina Tropical, Faculdade de Medicina, \\ Universidade de São Paulo, São Paulo, Brasil. \\ [2]. Faculdade de Medicina, Universidade Estadual do Pará, Pará, Brasil. \\ [3]. Departamento de Dermatologia e Radioterapia, Faculdade de Medicina de Botucatu, \\ Universidade Estadual Paulista, Botucatu, São Paulo, Brasil.
}

\begin{abstract}
Introduction: Freshwater stingray envenomations are an important cause of morbidity in riverine populations living in various regions of Brazil. The sequelae include temporary or permanent disability. This study aimed to identify sociodemographic, clinical, and therapeutic aspects related to stingray injuries in such populations. Methods: This cross-sectional study was conducted in the Extractive Reserve of Tapajos-Arapiuns, located in the municipalities of Santarém and Aveiro (Pará State). A convenience sample comprising 300 local adults was used to obtain data by means of a questionnaire/ interview. Results: Overall, 19 (6.3\%) participants reported having sustained a stingray injury in the 12 months prior to the study. All 19 were injured either while fishing $(n=13$ [68.4\%]) or engaging in other riverine activities. Most injuries $[n=14(73.7 \%)]$ occurred from September through November, and most injured respondents $[n=15(78.9 \%)]$ reported seeing stingrays at beaches. Severe pain and the appearance of ulcers in the later stages of envenomation were described by $18(94.7 \%)$ and $12(63.2 \%)$ participants, respectively. Conclusions: Freshwater stingray injuries, which should be considered occupational injuries, are common in the study area, especially in places like beaches or in the lakes that form during the dry season, when stingrays are routinely observed. A significant proportion of respondents was unaware of the correct first aid measures and had insufficient resources to treat the complications of these injuries in the locality where they reside. Interactive activities involving local residents - such as lectures and the distribution of simple pamphlets providing information about stingray injuries — are needed.
\end{abstract}

Keywords: Stings. Venomous animals. Freshwater stingrays. Potamotrygonidae. Amazon region.

\section{INTRODUCTION}

Brazil has the largest freshwater network in the world, most of which concentrated in the Amazon. Human occupation of the Amazon region started along the rivers with the formation of coastal communities $^{1,2}$. These communities are influenced by their close relationship with nature; their livelihood depends on the rivers and the water cycle ${ }^{1-3}$. Because of this close connection with the fluvial environment, injuries caused by venomous and other potentially dangerous aquatic animals are important causes of morbidity and of temporary or permanent work incapacity, especially among fishermen. Due to the frequency of injuries they inflict, stingrays of the Potamotrygonidae family constitute the most important group of injury-inducing aquatic animals in these areas ${ }^{4-6}$.

Corresponding author: Dr. Paulo Afonso Martins Abati.

e-mail: pauloabati@usp.br

Received 2 February 2017

Accepted 17 May 2017
The Potamotrygonidae family includes 25 species of stingrays, divided into four genera ${ }^{7}$. The largest number of species is found in the Amazon region. These stingrays are struggling to survive because fishing exerts pressure on their food supply, they are captured for commercial purposes (e.g., for display in aquariums), and are vulnerable to being captured during dry periods, which is when the risk of injuries to humans is also highes $t^{4-8}$. These stingrays are feared by the local populations due to the severity of the envenomation caused by the stingers located in the tail; up to four stingers may be present in the tail. These stingers are dentin-based structures covered with venom-producing cells (Figure 1) $)^{4-8}$. Perforating and/or lacerating injuries are caused by sharp, serrated stings that occur when these animals are stepped on or handled. Fishermen, bathers, people washing clothes, and other groups that remain in shallow areas such as fluvial beaches and lakes are exposed to this danger, especially during the Amazon dry season (July to December) ${ }^{4,8}$. 


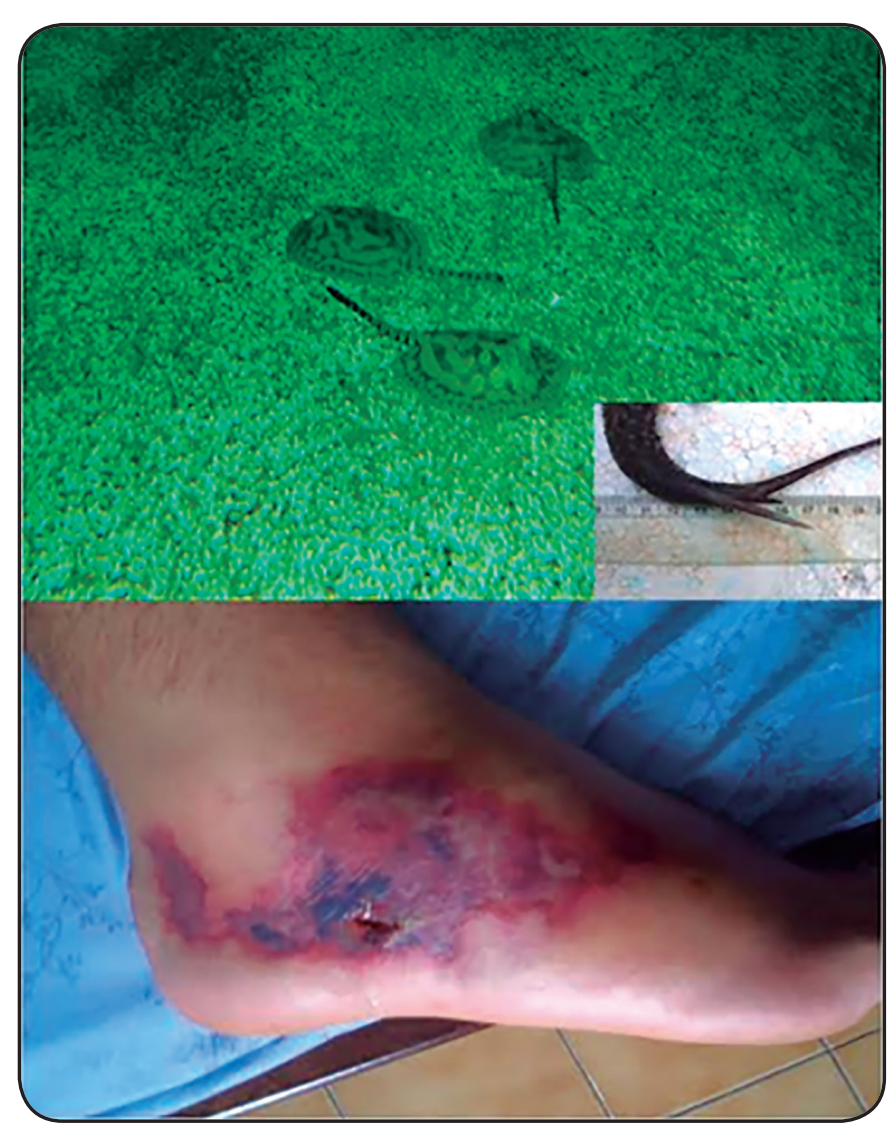

FIGURE 1 - Above: Specimens of Potamotrygon sp. of the Amazon region found in shallow waters with a sandy floor. Inset: Tail showing two serrated stingers. Below: Injury caused by a freshwater stingray, five days after the sting; severe necrosis, edema, and erythema are demonstrated.

The sting causes excruciating pain and marked local inflammation that manifests as severe edema and erythema (Figure 1). Injuries may be associated with skin necrosis and serious bacterial infections, which can cause temporary or permanent work inability, particularly among fishermen ${ }^{4-10}$. The only effective first aid treatment is to soak the affected area (usually the extremities) in tolerably hot water for 30-90 minutes; this promotes vasodilation (counterbalancing the intense vasoconstriction caused by the venom) and helps with thermal inactivation of heat-labile toxins ${ }^{7,8,10}$. No antivenom is available ${ }^{4-8}$.

Studies on the diversity of stingrays and the injuries they inflict in humans in the Tapajós River basin are limited to a few reports.. In a recent study in the lower Rio Juruá (in the State of Amapá), Potamotrygon motoro and Potamotrygon scobina species were identified ${ }^{4}$. This study aimed to identify the sociodemographic and cultural aspects as well as the clinical and therapeutic aspects related to injuries caused by freshwater stingrays among residents of riverside communities located in the Extractive Reserve [Reserva Extrativista (RESEX)] TapajósArapiuns, in the basin of the Tapajós River, Para State.

\section{METHODS}

Using a structured questionnaire, we invited residents of the riverine communities of the RESEX Tapajós-Arapiuns and users of the Family Health Unit Fluvial "Abaré" [Unidade de Saúde da Familia Fluvial "Abaré" (USFF Abaré)] to participate in the study (Figure 2). The health care rounds of the USFF Abaré in the Tapajós River communities usually last approximately 10 days. Services are generally provided to two distinct communities each day. Interviews were conducted with participants during a 10-day trip in the second half of 2010.

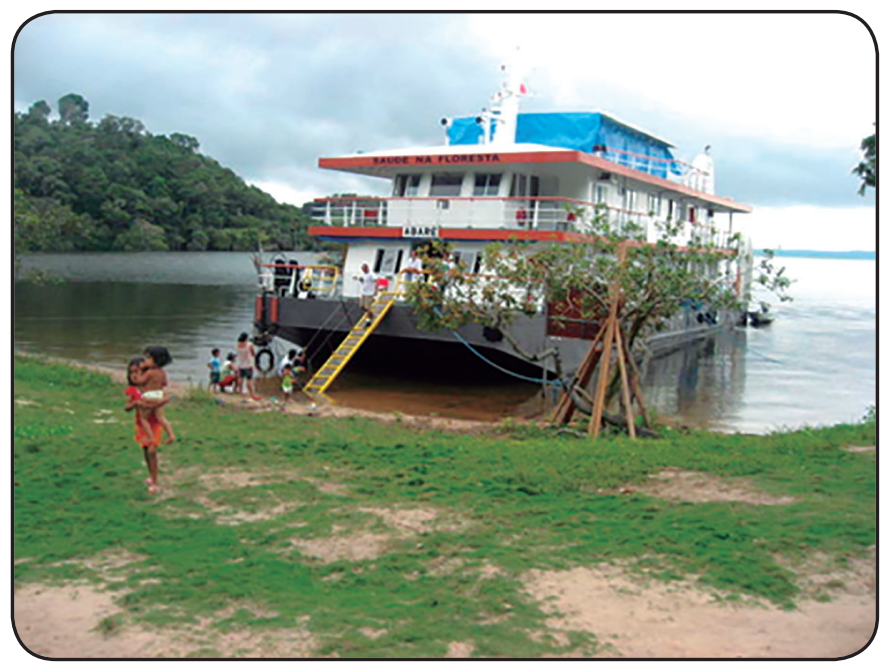

FIGURE 2 - The Abaré Hospital Boat of the Family Health Unit in attendance on the banks of the Tapajós River in RESEX. RESEX: Reserva Extrativista.

Convenience samples were used: The first 15 patients assisted by the River Family Health Unit in the morning and the 15 first assisted in the afternoon at each riverside community attended to by the USFF Abaré, were selected. Thus, a total convenience sample of 300 participants from 20 communities was interviewed during the 10-day study period. The inclusion criteria were: registered users of the Fluvial Family Health Unit services, age $>18$ years, and residents of riverine areas spanning the service provision area of the USFF Abaré. In addition to socio-cultural and demographic data, participants were questioned about the occurrence of injuries in the 12-month period preceding the date of the interview.

\section{Ethical considerations}

Approval to conduct the study was granted by the Ethics Committee of the State University of Pará, registered under the number $1.885 .173 / 2016$.

\section{RESULTS}

Table 1 and Table 2 describe the sociodemographic characteristics of the participants. The majority (69\%) were women. Overall, 19 (6.3\%) participants had suffered a stingray injury in the preceding 12 months: 14 of these participants were men, $17(90 \%)$ were aged 25-65 years, and all reported working as fishermen/ farmers. Table 2 describes the environmental and seasonal variables associated with encountering stingrays in their natural environment. According to respondents, stingrays were most commonly viewed in the dry season, at beaches, and in the sand. 
TABLE 1

Characteristics and occurrence of recent injury from a stingray among residents of the RESEX Tapajós-Arapiuns.

\begin{tabular}{|c|c|c|}
\hline Variable & Number & Percentage \\
\hline male & 94 & 31.0 \\
\hline \multicolumn{3}{|l|}{ Age (years) } \\
\hline $18-25$ & 52 & 17.3 \\
\hline $36-45$ & 69 & 23.0 \\
\hline $46-55$ & 45 & 15.0 \\
\hline $56-65$ & 28 & 9.3 \\
\hline $66-75$ & 17 & 5.7 \\
\hline$>76$ & 4 & 1.3 \\
\hline fisherman & 105 & 35.0 \\
\hline home worker & 26 & 8.7 \\
\hline community Health Agent & 8 & 2.7 \\
\hline others & 28 & 9.3 \\
\hline \multicolumn{3}{|c|}{ Sustained an injury from a stingray in the last 12 months } \\
\hline yes & 19 & 6.3 \\
\hline no & 281 & 93.7 \\
\hline Total & 300 & \\
\hline
\end{tabular}

RESEX: Reserva Extrativista.

TABLE 2

Seasonality and characteristics of the places where freshwater stingrays are found most commonly, according to the residents of the RESEX Tapajós-Arapiuns.

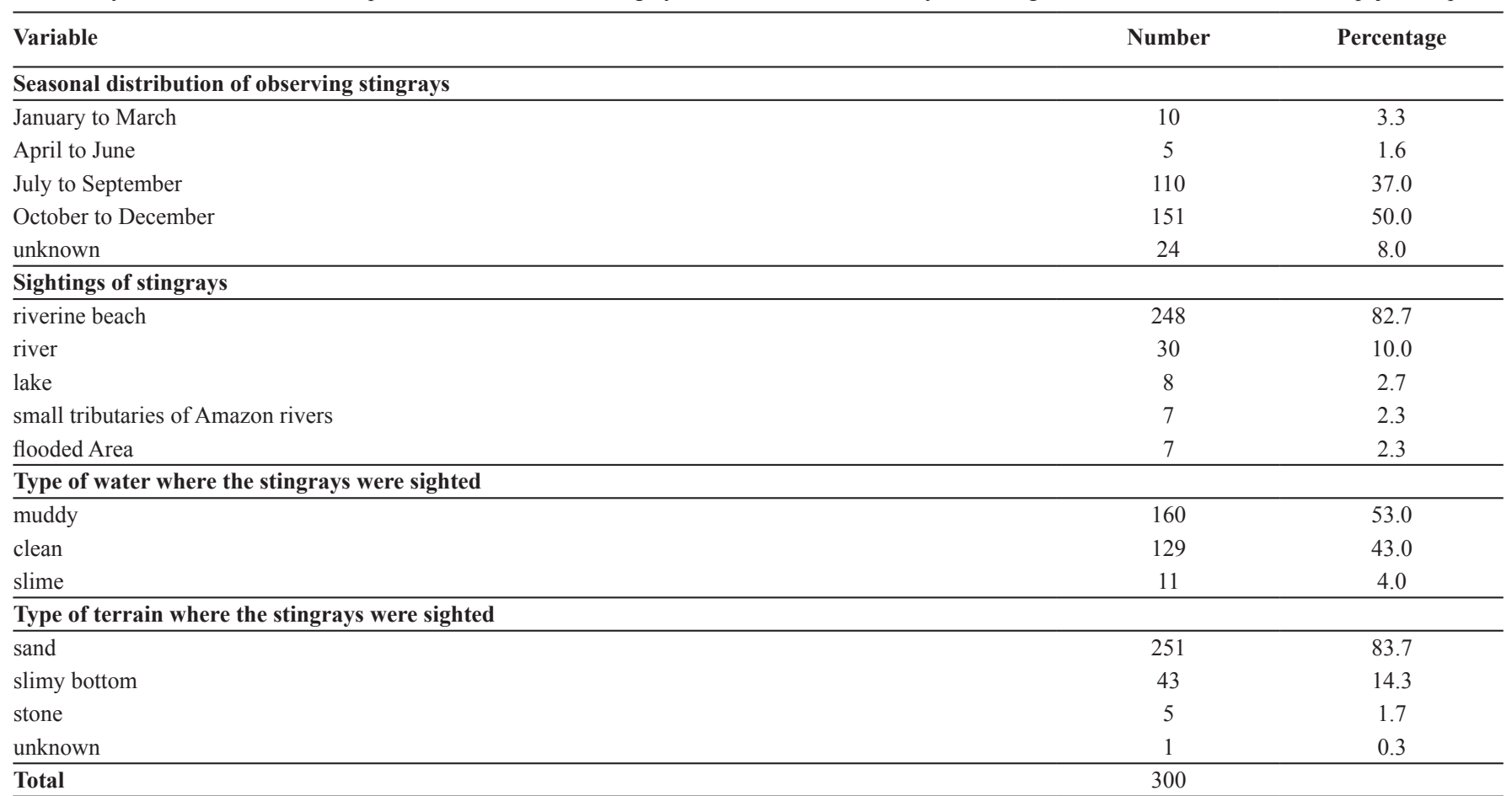

RESEX: Reserva Extrativista. 
Most stingray injuries occurred when the victims were fishing $[n=13(68.4 \%)]$ and during the period September through November $[n=14(73.7 \%)]$, the final period of drought in the region. The freshwater stingray injuries occurred at the beaches $[n=15(80 \%)]$ and in the black waters $[n=10(52.6 \%)]$. Stingrays were seen in clear $(n=9)$ and/or in sandy bottomed [ $n$ $=17(89.5 \%)]$ water sources. Six respondents reported having been injured while engaging in activities other than fishing, such as bathing, washing clothes, loading and unloading boats, or while cleaning canoes.

The appearance of ulcers in the later stages of injury was described by $12(63 \%)$ participants. The main symptom experienced was intense pain, reported by 18 (94.7\%) individuals. Local edema and erythema were mentioned by $8(42 \%)$ participants. Initial therapeutic measures used after envenomation included homemade medications [ $\mathrm{n}=10(52.6 \%)]$ and/ or immersion of the affected body part in hot water $[\mathrm{n}=10$ $(52.6 \%)]$. Of those injured, 13 did not seek health care after the envenomation.

The participants also reported having used a combination of therapeutic measures from the popular folklore to prevent complications of stings: 17 tried not to eat greasy food (known locally as remosa food), 16 avoided stepping on chicken feces, 15 abstained from sex, 15 tried not to step on hot coals or earth, and 13 avoided eye contact with pregnant women.

\section{DISCUSSION}

The injuries caused by freshwater stingrays are common in the study area, as shown by the data obtained via the questionnaire. The study identified a high number of stingray injuries in the 12 months preceding the survey. Moreover, the fear caused by these fish in the local population was evident. This fear results from the risk of exposure to stingrays/ stingray injuries while working, particularly during the dry period and in environments such as beaches or lakes (which form during the dry season), where stingrays are routinely observed.

The presence of these aquatic animals in these environments is cause for concern not only for fishermen, but also for women washing clothes at the riverbanks and for those who use the river for transportation and bathing; the latter groups mainly comprise women. These facts may explain the negative impact of fishing, as documented in a study conducted in the lower Rio Juruá in the Amazon, where $60 \%$ of freshwater stingrays captured by nets were sacrificed. These actions can be justified, according previous studies, by the fear and/ or hatred that fishermen feel toward these animals and because of the cultural and mystical aspects related to stingray injuries ${ }^{4,7}$.

Clinical data show that the severity of envenomation is particularly important when considering the morbidity of accidents. In addition, fishermen and riverside inhabitants (women washing clothes or people using the river to move between communities to work, for example, as teachers and community health workers) receive no support if they are temporarily unable to work due to sickness. Thus, when an injury occurs, initial support is minimal; support may be received later, but temporary or permanent disability may have already occurred. The difficulty these riverside populations experience in accessing primary health care further reinforces their search for alternative treatments. Such treatments are usually passed down through oral tradition and are influenced by the culture of the indigenous people ${ }^{3}$.

The envenomation from a stingray sting causes excruciating pain and intense initial inflammation, with ischemia at the injury site occurring later on. Skin necrosis cannot be avoided, but the pain can be minimized by soaking the injured part in hot water; almost $50 \%$ of the respondents did not know this 9 . The resulting ulcers heal with difficulty and may persist for months, especially if not treated with strict cleaning and prevention of secondary bacterial infections. Secondary infection is almost always caused by microorganisms found in the aquatic environment, especially bacteria of the genus Aeromonas ${ }^{11}$. Tetanus may occur after sustaining a stingray injury as its development is not unusual in those with necrotic tissue; necrosis is an essential pre-condition for the multiplication of Clostridium tetani. Thus, provision of tetanus prophylaxis is a main focus of treatment post-injury ${ }^{11}$.

There is no specific treatment for freshwater stingray envenomation; antivenom is not available. The recommended treatment measures are intensive cleaning of the lesion and immersing the affected limb in hot water (approximately $60^{\circ} \mathrm{C}$ ), due to the heat-labile properties of some of the toxins in the venom and the vasodilation caused by the hot water helps to counter the intense vasoconstriction and resultant ischemia induced by the venom. This measure usually decreases the pain associated with the injury ${ }^{12,13}$. If the pain is not controlled after $2 \mathrm{~h}$, local and systemic analgesics, including opioids, should be used ${ }^{7}$.

In conclusion, this study shows that a significant portion of the population interviewed was unaware of the correct first aid measures for stingray injuries and were unable to afford treatment for injury complications in the locality in which they reside. The popular therapeutic measures mentioned, that show striking elements of riverside culture, are not innocuous; they may aggravate the injury. In addition to the activities currently provided by the programs assisting the communities bordering the upper Rio Tapajós region, interactive activities that involve local residents - such as lectures and the distribution of simple pamphlets providing information about this health problem are needed.

\section{Conflicts of Interest}

The authors declare that have no conflicts of interest.

\section{REFERENCES}

1. Diegues AC. Etnoconservação da natureza: enfoques alternativos. In: Diegues AC, editor. Etnoconservação. Novos rumos para a conservação da natureza. HUCITEC. São Paulo: NUPAUB-USP; 2000. p. 1-46.

2. Fischer CFA, Chagas AGA, Dornelles LDC. Pesca de águas interiores. Ibama. Coleção Meio Ambiente, Série Estudos Pesca; 1992. p. 361-80.

3. Amaral S, Dal'Asta, AP, Brigatti N, Pinho CMD, Medeiros LCC, Andrade PR, et al. Comunidades ribeirinhas como forma 
socioespacial de expressão urbana na Amazônia. R Bras Est Pop. 2013;30(2):367-99.

4. Oliveira AT, Lima EC, Silva Paes L, Santos SM, Araújo RL, PantojaLima J, et al. Relação entre as populações naturais de arraias de água doce (Myliobatiformes: Potamotrygonidae) e pescadores no baixo rio Juruá, Estado do Amazonas, Brasil. Biota Amazonia. 2015;5(3):108-11.

5. Haddad Jr V. Atlas de animais aquáticos perigosos do Brasil: guia médico de diagnóstico e tratamento de acidentes. 1a ed. São Paulo: Editora Roca; 2000.

6. Garrone Neto D, Haddad Jr V. Acidentes Por Raias. In: Cardoso JLC, França FOS, Wen FH, Málaque CM, Haddad Jr V, editores. Animais peçonhentos no Brasil: biologia, clínica e terapêutica dos acidentes. São Paulo: Editora Sarvier; 2009. p. 295-305.

7. Haddad Jr V, Cardoso JLC, Garrone Neto D. Injuries by marine and freshwater stingrays: history, clinical aspects of the envenomations and current status of a neglected problem in Brazil. J Venom Anim Toxins Incl Trop Dis. 2013;19:1-11.

8. Reckziegel GC, Dourado FS, Garrone Neto D, Haddad Jr V. Injuries caused by aquatic animals in Brazil: an analysis of the data present in the information system for notifiable diseases. Rev Soc Bras Med Trop. 2015;48(4):460-67.

9. Rosa RS, Charvet-Almeida P, Quijada CCD. Biology of the South American Potamotrygonidae Stingrays. In: Carrier JF, Musick JA, Heithaus MR. Sharks and their relatives II: biodiversity, adaptive physiology, and conservation. CRC Press; 2010. p. 241-86.

10. Pedroso CM, Jared C, Charvet-Almeida P, Almeida MP, Garrone Neto D, et al. Morphological characterization of the venom secretory epidermal cells in the stinger of marine and freshwater stingrays. Toxicon. 2007;50(5):688-97.

11. Torrez PP, Quiroga MM, Said R, Abati PA, França FOS. Tetanus after envenomations caused by freshwater stingrays. Toxicon. 2015;97:32-5.

12. Garrone Neto D, Haddad Jr V. Arraias em rios da região Sudeste do Brasil: locais de ocorrência e impactos sobre a população. Rev Soc Bras Med Trop. 2010; 43(1):82-8.

13. Haddad V Jr, Garrone Neto D, de Paula Neto JB, de Luna Marques FP, Barbaro KC. Freshwater stingrays: study of epidemiologic, clinic and therapeutic aspects based on 84 envenomings in humans and some enzymatic activities of the venom. Toxicon. 2004;43(8):287-94. 